\title{
Fermentative Metabolism and Organic Acid Concentrations in Fruit of Selected Strawberry Cultivars with Different Tolerances to Carbon Dioxide
}

\author{
J. Pablo Fernández-Trujillo, Jacqueline F. Nock, and Christopher B. Watkins ${ }^{1}$ \\ Department of Fruit and Vegetable Science, Cornell University, Ithaca, NY 14853
}

\begin{abstract}
AdDitional INDEX wORDs. Fragaria $\times$ ananassa, acetaldehyde, ethanol, succinate, pyruvate decarboxylase, alcohol dehydrogenase

Abstract. Effects of $20 \mathrm{kPa} \mathrm{CO}$ treatments on concentrations of fermentation products, organic acids, and activities of pyruvate decarboxylase (PDC) and alcohol dehydrogenase (ADH), were measured in fruit of selected strawberry cultivars (Fragaria $\times$ ananassa Duch. ‘Annapolis', ‘Cavendish', 'Honeoye', 'Kent', 'Jewell', 'Lateglow', and 'NorthEast'). Acetaldehyde, ethanol, and ethyl acetate concentrations accumulated in $\mathrm{CO}_{2}$-treated fruit of 'Honeoye' and 'Kent', but not in 'Cavendish' or 'Annapolis'. The former two cultivars were classified as intolerant to high $\mathrm{CO}_{2}$ and the latter two as tolerant to high $\mathrm{CO}_{2}$. Activities of $\mathrm{PDC}$ and $\mathrm{ADH}$ were higher in $\mathrm{CO}_{2}$-treated than in air-treated fruit of the tolerant cultivars but not in the intolerant cultivars. Succinate accumulated in fruit of all cultivars, but concentrations were higher in the tolerant than in the intolerant cultivars. Results are discussed in relation to tolerance of fruit to $\mathrm{CO}_{2}$.
\end{abstract}

Physiological and biochemical factors associated with tolerance of commodities to $\mathrm{CO}_{2}$ treatments are not well understood. One focus of research has been on fermentation, as under anaerobic conditions, increased activities of pyruvate decarboxylase (PDC) and alcohol dehydrogenase (ADH), which catalyze the reactions between pyruvate, acetaldehyde, and ethanol, are common (Kennedy et al., 1992). Thus pyruvate oxidation and NADH use can proceed while electron transport and oxidative phosphorylation are inhibited, and ATP can be produced, albeit at markedly reduced levels by substrate phosphorylation. However, activities of PDC and ADH increase only slightly, or even decrease, in strawberries and other fruits under high $\mathrm{CO}_{2}$ atmospheres; the changes in response to $\mathrm{CO}_{2}$ typically being much lower than those observed under low $\mathrm{O}_{2}$ (Ke et al., 1994a, 1994b, 1995; Nanos et al., 1992).

A second focus has been on accumulation of succinate in response to elevated $\mathrm{CO}_{2}$ atmospheres. Succinate accumulates in leaves and stems (Ke et al., 1993; Romo-Parada et al., 1989) and fruit (Wagner, 1974; Yang et al., 1998), and has been ascribed to inhibition of succinate dehydrogenase $(\mathrm{SDH})$ in high $\mathrm{CO}_{2}$ concentrations (Frenkel and Patterson, 1973; Ke et al., 1993; Shipway and Bramlage, 1973). Hulme (1956) proposed that succinate is toxic to plant tissues, and its accumulation was responsible for $\mathrm{CO}_{2}$ injury of apple fruit [Malus sylvestris (L.) Mill var. domestica (Borkh.) Mansf.].

Strawberries (Fragaria $\times$ ananassa) are generally tolerant to high $\mathrm{CO}_{2}$ concentrations, and in major strawberry producing regions such as California, $\mathrm{CO}_{2}$ treatments of 15 to $20 \mathrm{kPa}$ are injected into plastic pallet shrouds to maintain flesh firmness and reduce decay incidence (Mitchell, 1992). A major limitation to the use of high $\mathrm{CO}_{2}$ treatments in controlled atmosphere (CA) and modified atmosphere (MA) packaging, however, has been devel-

\footnotetext{
Received for publication 10 Mar. 1999. Accepted for publication 10 Aug. 1999. This work was supported by a postdoctoral grant to J.P. Fernandez-Trujillo (Séneca Foundation, Región de Murcia, Spain), and by Federal Formula Funds, regional project NE103. We thank Samantha Andersen for excellent technical assistance, and Al Purvis, Randy Beaudry, and Ian Merwin for helpful reviews. The cost of publishing this paper was defrayed in part by the payment of page charges. Under postal regulations, this paper therefore must be hereby marked advertisement solely to indicate this fact.

${ }^{1}$ To whom reprint requests should be addressed; e-mail: cbw3@cornell.edu.
}

opment of off-flavor in the fruit resulting from anaerobic fermentation (Ke et al., 1991, 1994a; Larsen and Watkins, 1995a, 1995b). In general, off-flavor intensity increases with higher $\mathrm{CO}_{2}$ concentrations, and time of exposure to the gas (Ke et al., 1991; Larsen and Watkins, 1995a). However, variation in strawberry response to $\mathrm{CO}_{2}$ treatment has been found. No off-flavor development was detected at $\mathrm{CO}_{2}$ concentrations as high as $20 \mathrm{kPa}$ (Couey and Wells, 1970; Harris and Harvey, 1973), and even 80 $\mathrm{kPa}$ for limited time periods (Ke et al., 1991), whereas others found problems at concentrations as low as $10 \mathrm{kPa}$ (Browne et al., 1984). The reasons for differences between studies are not known, but genetic variation in fruit tolerance to high $\mathrm{CO}_{2}$ treatments was indicated by different fermentation product concentrations in seven strawberry cultivars kept in $20 \mathrm{kPa} \mathrm{CO}$ for $7 \mathrm{~d}$ (Watkins et al., 1999). Such variation has significance in selection of cultivars for storage and/or transport under MA/CA conditions.

Differences in fermentation responses of strawberry cultivars to $20 \mathrm{kPa} \mathrm{CO}$ provide useful material to dissect aspects of fruit tolerance to the gas. In this study, our objective was to study activities of PDC and $\mathrm{ADH}$, and changes in organic acid concentrations, in relation to accumulation of fermentation products in fruit of cultivars treated with $\mathrm{CO}_{2}$-enriched atmospheres.

\section{Material and Methods}

Strawberry cultivars used in these experiments were harvested at the New York Agricultural Experiment Station, Geneva ('Annapolis', 'Cavendish', 'Honeoye', and 'Kent') and the Cornell Orchard, Ithaca ('Cavendish', 'Honeoye', 'Jewel', 'Lateglow', and 'Northeast'). Fruit of each cultivar were harvested at the white tip/orange stage of maturity. Harvest dates in 1998 ranged from 8 June to 18 June for the Geneva-grown cultivars. Harvest dates for Ithaca-grown cultivars, were 23 June for 'Jewel', and 14 June for the others (Table 1). Fruit harvested in Geneva were transported $(\approx 1 \mathrm{~h})$ to the postharvest laboratory at Ithaca. Fruit were sorted quickly to remove any underripe, overripe, or damaged fruit and 20-fruit samples were placed into 1-L glass jars at $2{ }^{\circ} \mathrm{C}$ for $3 \mathrm{~h}$ to cool the fruit, with the exception of fruit in Expt. 3 , which were held at $20{ }^{\circ} \mathrm{C}$ throughout, before atmosphere 
treatments were applied. Jars, with lids fitted with inlet and outlet ports, were then attached to a flow-through system $\left(50 \mathrm{~mL} \cdot \mathrm{min}^{-1}\right)$ containing humidified premixed atmospheres of air or $20 \mathrm{kPa}$ $\mathrm{CO}_{2}$ in air. $\mathrm{O}_{2}$ and $\mathrm{CO}_{2}$ levels where checked daily by gas chromatography (model 1200 gas partitioner, Fisher Scientific, Springfield, N.J.). The $20 \mathrm{kPa} \mathrm{CO}_{2}$ concentration was maintained within $1 \mathrm{kPa}$ of the target concentration throughout the experiment. Fruit were assessed after the initial cooling period of $3 \mathrm{~h}$, or immediately after removal from storage. All experiments were run in triplicate.

Three experiments were conducted: 1) 'Cavendish', 'Northeast', 'Honeoye', and 'Lateglow' strawberries were stored at each atmosphere at $2^{\circ} \mathrm{C}$ and sampled after $3 \mathrm{~d} ; 2$ ) 'Annapolis', 'Cavendish', 'Honeoye', and 'Kent' strawberries were stored at each atmosphere at $2{ }^{\circ} \mathrm{C}$ for $9 \mathrm{~d}$ and replicates removed at $0,3,6$ or $9 \mathrm{~d}$; and 3 ) 'Jewel' strawberries were stored at each atmosphere at 2 and $20^{\circ} \mathrm{C}$ for $9 \mathrm{~d}$ and replicates removed at $0,1,2,3,6$, or $9 \mathrm{~d}$.

At each sampling time, 15 to 20 berries were peeled rapidly to remove achenes and frozen immediately in liquid $\mathrm{N}_{2}$. The frozen fruit were kept at $-80{ }^{\circ} \mathrm{C}$ until used for measurement of ethanol, acetaldehyde and ethyl acetate, and organic acids. In Expt. 2, three-fruit samples per replication (unfrozen) were removed for assay of PDC and ADH activities.

FERMENTATION PRODUCTS. Frozen samples were powdered in liquid $\mathrm{N}_{2}$ and $5 \mathrm{~g}$ of powder weighed into a $20 \mathrm{~mL}$ vial, which was sealed and placed into a water bath maintained at $40^{\circ} \mathrm{C}$ for $20 \mathrm{~min}$. Headspace samples of $0.5 \mathrm{~mL}$ were removed from the bottles with a gas tight glass syringe and injected immediately into a gas chromatograph (model 5890; Hewlett-Packard, Wilmington, Del.) fitted with a $15 \mathrm{~m} \times 0.53 \mathrm{~mm}$ wide bore capillary column with a coating thickness of $1.0 \mu \mathrm{m}$ (Stabilwax, Restek Corp., Bellefonte, $\mathrm{Pa}$.), and attached to an integrator (Hewlett-Packard 3396A). The oven temperature was $45^{\circ} \mathrm{C}$, with injector and detector temperatures of 230 and $240{ }^{\circ} \mathrm{C}$, respectively. Gas flow rates for hydrogen, air, and helium were 35,175 , and $6 \mathrm{~mL} \cdot \mathrm{min}^{-1}$, respectively. Acetaldehyde, ethanol, and ethyl acetate were identified from retention times and standard curves obtained using authentic compounds (Fisher Chem. Co., Pittsburg, Pa.). Detection limits for acetaldehyde, ethyl acetate, and ethanol were 0.004, 0.005, and $0.002 \mu \mathrm{mol} \cdot \mathrm{g}^{-1}$, respectively.

Organic ACIDS. One gram of powdered tissue was weighed into a $50 \mathrm{~mL}$ polyethylene centrifuge tube and kept at $-80^{\circ} \mathrm{C}$ until adding $0.5 \mathrm{~mL} 66.6 \mathrm{mmol} \cdot \mathrm{L}^{-1}$ tartaric acid in water as an internal standard (Reyes et al., 1982). Extraction and analyses of acids were based on the method of Mattick et al. (1970). For extraction, $20 \mathrm{~mL} 21 \mathrm{~mol} \cdot \mathrm{L}^{-1}$ ethanol (i.e., 95\%) were added to lots of eight samples kept in a water bath at $50{ }^{\circ} \mathrm{C}$. Samples were stirred periodically with a glass-stirring rod during a 10 min extraction period. Then tubes were centrifuged at $5000 \mathrm{~g}_{\mathrm{n}}$ for $5 \mathrm{~min}$ at $22^{\circ} \mathrm{C}$ and the supernatant was poured into another $50 \mathrm{~mL}$ centrifuge tube. This step was repeated and the supernatants were combined.

To precipitate organic acids, $2 \mathrm{~mL}$ of a saturated lead acetate solution $\left(422 \mathrm{mmol} \cdot \mathrm{L}^{-1}\right)$ and $0.1 \mathrm{~g}$ celite were added. Tubes were sonicated for $45 \mathrm{~min}$ and then centrifuged at $5000 \mathrm{~g}_{\mathrm{n}}$ for $5 \mathrm{~min}$. The supernatant was decanted and discarded, the precipitate washed with $20 \mathrm{~mL} 21 \mathrm{~mol} \cdot \mathrm{L}^{-1}$ hot ethanol, stirred with glassstirring rod, and centrifuged again at $5000 g_{n}$ for $5 \mathrm{~min}$. The precipitate was washed with $10 \mathrm{~mL}$ anhydrous diethyl ether and

Table 1. Volatile compounds and organic acids in four strawberry cultivars sampled at harvest and after storage for $3 \mathrm{~d}$ in air or $20 \mathrm{kPa} \mathrm{CO}_{2}$ in air at $2{ }^{\circ} \mathrm{C}$.

\begin{tabular}{|c|c|c|c|c|c|c|}
\hline \multirow[b]{2}{*}{$\begin{array}{l}\text { Cultivar and } \\
\text { treatment }\end{array}$} & \multirow[b]{2}{*}{$\begin{array}{l}\text { Time } \\
\text { (d) }\end{array}$} & \multicolumn{3}{|c|}{$\begin{array}{l}\text { Volatile compounds } \\
\left(\mu \mathrm{mol} \cdot \mathrm{g}^{-1} \text { fresh } \mathrm{wt}\right)\end{array}$} & \multicolumn{2}{|c|}{$\begin{array}{c}\text { Organic acids } \\
\left(\mu \mathrm{mol} \cdot \mathrm{g}^{-1} \text { fresh } \mathrm{wt}\right)\end{array}$} \\
\hline & & Acetaldehyde & Ethanol & $\begin{array}{c}\text { Ethyl } \\
\text { acetate }\end{array}$ & Succinate & Malate \\
\hline \multicolumn{7}{|l|}{ Cavendish } \\
\hline At harvest & 0 & 0.05 & $\mathrm{ND}^{\mathrm{z}}$ & 0.03 & 0.3 & 13.9 \\
\hline Air & 3 & 0.03 & ND & 0.04 & 0.3 & 16.4 \\
\hline $\mathrm{Air}+20 \mathrm{kPaCO}_{2}$ & 3 & 0.02 & 0.06 & 0.06 & 1.8 & 13.4 \\
\hline \multicolumn{7}{|l|}{ Honeoye } \\
\hline At harvest & 0 & 0.04 & 0.02 & 0.03 & 0.4 & 10.9 \\
\hline Air & 3 & 0.04 & 0.10 & 0.03 & 0.3 & 10.9 \\
\hline $\mathrm{Air}+20 \mathrm{kPa} \mathrm{CO}$ & 3 & 0.32 & 3.51 & 0.05 & 1.4 & 9.2 \\
\hline \multicolumn{7}{|l|}{ Lateglow } \\
\hline At harvest & 0 & 0.04 & ND & 0.03 & 0.3 & 10.0 \\
\hline Air & 3 & 0.02 & ND & 0.04 & 0.3 & 10.7 \\
\hline $\mathrm{Air}+20 \mathrm{kPa} \mathrm{CO}$ & 3 & 0.11 & 1.65 & 0.42 & 1.6 & 7.1 \\
\hline \multicolumn{7}{|l|}{ Northeast } \\
\hline At harvest & 0 & 0.04 & ND & 0.03 & 0.4 & 12.5 \\
\hline Air & 3 & 0.00 & ND & 0.03 & 0.4 & 12.6 \\
\hline \multirow[t]{2}{*}{$\mathrm{Air}+20 \mathrm{kPa} \mathrm{CO}$} & 3 & 0.01 & 0.11 & 0.04 & 0.8 & 12.5 \\
\hline & df & \multicolumn{5}{|c|}{ Significance (MS and $P)^{\mathrm{y}}$} \\
\hline Cultivar (C) & 3 & $0.024^{* * *}$ & $0.035^{* * *}$ & $2.83^{* * * *}$ & $0.01^{\mathrm{NS}}$ & $50.1^{\text {***\% }}$ \\
\hline Atmosphere (A) & 2 & $0.029^{* *}$ & $0.046^{* * *}$ & $6.95^{* * * *}$ & $7.79^{* * * *}$ & $13.6^{* *}$ \\
\hline $\mathrm{C} \times \mathrm{A}$ & 6 & $0.018^{* *}$ & $0.035^{* * *}$ & $2.57^{* * * *}$ & $0.30^{* * * *}$ & $2.8^{\mathrm{NS}}$ \\
\hline Error & 24 & 0.002 & 0.002 & 0.18 & 0.04 & 1.8 \\
\hline
\end{tabular}

${ }^{\mathrm{z}} \mathrm{ND}=$ not detectable.

${ }^{\mathrm{y}} \mathrm{MS}$ values for succinate were calculated after transformation to its natural logarithm.

Ns,**,**** Nonsignificant at $P>0.05$ or significant at $P \leq 0.01$ or 0.001 , respectively. 
vortexed. The precipitate was dried by leaving the samples in the hood overnight. The dried precipitate was broken up to a powder with a spatula and transferred to a $5 \mathrm{~mL}$ serum bottle.

For derivatization, $1 \mathrm{~mL}$ silyl grade pyridine was added before capping the bottle and mixing with a vortex. Then, $0.2 \mathrm{~mL}$ hexamethyldisilazane and $0.2 \mathrm{~mL}$ trimethylchlorosilane (Sigma Chem. Co., St. Louis, Mo.) were added, the bottles again capped and mixed with a vortex. After $3 \mathrm{~h}$, the bottles were centrifuged at $5000 g_{\mathrm{n}}$ for $5 \mathrm{~min}$. A $1 \mu \mathrm{L}$ sample was injected into a gas chromatograph (Hewlett Packard 5890), fitted with a $15 \mathrm{~m} 0.53$ $\mathrm{mm}$ ID wide-bore fused silica column with a film thickness of 1.5 $\mu \mathrm{m}$ (Rtx-1 Crossbond $100 \%$ dimethyl polysiloxane, Restek Corp.). The column temperature program was $100{ }^{\circ} \mathrm{C}$ for $2 \mathrm{~min}$, then increasing at $8{ }^{\circ} \mathrm{C} \mathrm{min}-1$ to $240{ }^{\circ} \mathrm{C}$. The injector and detector temperatures were $250{ }^{\circ} \mathrm{C}$ and $290{ }^{\circ} \mathrm{C}$, respectively. Gas flow rates were 35,150 , and $8 \mathrm{~mL} \cdot \mathrm{min}^{-1}$ for hydrogen, air, and helium, respectively. Organic acid identification was by comparison of retention times using authentic compounds (Sigma Chem. Co.), alone and with spiked sample tissue.

ENZYME ASSAYS. Procedures used were modified from Ke et al. (1994a) and Mitchell and Jelenkovic (1995). Flesh tissue from three-fruit samples was bulked and $3 \mathrm{~g}$ of tissue homogenized in a cold mortar with a pestle with $10 \mathrm{~mL} 100 \mathrm{mmol} \cdot \mathrm{L}^{-1} 2-(\mathrm{N}-$ morpholino)ethane-sulfonic acid (MES) buffer ( $\mathrm{pH} 6.5$ ), 2\% w/v soluble polyvinylpyrrolidone, $1 \mathrm{mmol} \cdot \mathrm{L}^{-1} \mathrm{ZnSO}_{4}, 10 \mathrm{mmol} \cdot \mathrm{L}^{-1} \mathrm{~b}$ mercaptoethanol, $1 \mathrm{mmol} \cdot \mathrm{L}^{-1}$ benzamidine hydrochloride, and 5 $\mathrm{mmol} \cdot \mathrm{L}^{-1} \varepsilon$-amino-n-caproic acid. The extract was centrifuged at $15,000 g_{\mathrm{n}}$ at $4{ }^{\circ} \mathrm{C}$ for $20 \mathrm{~min}$ to pellet insoluble debris, and the supernatant was used as the enzyme source. All solutions and enzyme extracts were kept on ice. Enzyme assays were carried out at $23^{\circ} \mathrm{C}$. PDC and ADH were assayed by measuring NADH oxidation as described by Ke et al. (1994a) using a spectrophotometer (model DU-60; Beckman Instruments, Fullerton, Calif.).

Statistical analysis. Data were subjected to ANOVA using general linear model procedures for calculation of least squared means and LSDS. To assume normal distribution, a normal probability plot of each different compound content was examined by using Minitab software v 11.12 (Minitab, Inc., State College, Pa.). When log-normal distributions resulted, data were transformed to natural logarithms. Values at harvest were not considered in analyses of Expts. 2 and 3 . For fermentation product analysis, results from data transformed to its respective 0.1 and 0.25 root were compared with original ones to reduce variability effects. When the atmosphere factor or its interactions were significant, an additional ANOVA was performed by substituting the cultivar factor by a tolerance variable according to the presence or absence of fermentation product accumulation. LSDS were calculated at $P=0.05$.

\section{Results}

EXPERIMENT 1. Fruit of four cultivars were stored under $20 \mathrm{kPa} \mathrm{CO}_{2}$ for $3 \mathrm{~d}$ at $2{ }^{\circ} \mathrm{C}$. During this time, acetaldehyde and ethanol concentrations increased in $\mathrm{CO}_{2}$-treated fruit of 'Honeoye' and 'Lateglow', but not in 'Cavendish' or 'Northeast' (Table 1). Ethyl acetate concentrations also increased in
'Lateglow'. Concentrations of the fermentation products in airstored fruit generally did not change from those at harvest. Succinate concentrations increased in $\mathrm{CO}_{2}$-treated fruit, although to a lesser extent in 'Northeast'. In this cultivar the increased succinate concentration was not statistically significant at $3 \mathrm{~d}$. Malate concentrations were not affected consistently by treatment, being lower in $\mathrm{CO}_{2}$-treated fruit than air-treated fruit in 'Lateglow', and higher after 3 din air than at harvest in 'Cavendish' . Citrate/isocitrate concentrations were affected by cultivar, but not by treatment (data not shown). The presence or absence of fermentation product accumulation as a factor in statistical analyses revealed an overall effect on malate of 9.8 and $13.5 \mu \mathrm{mol} \cdot \mathrm{g}^{-1}$ $(P<0.001)$, respectively, and citrate/isocitrate of 28.6 and 23.5 $\mu \mathrm{mol} \cdot \mathrm{g}^{-1}(P \leq 0.002)$, respectively.

EXPERIMENT 2. Two groups of cultivar response to $\mathrm{CO}_{2}$ were chosen on the basis of the previous experiment (Table 1) and data obtained by Watkins et al. (1999). Fruit were treated with $\mathrm{CO}_{2}$ or air for up to $9 \mathrm{~d}$. The first group, represented by 'Annapolis' and 'Cavendish', did not accumulate appreciable levels of acetaldehyde, ethanol, or ethyl acetate (Fig. 1). A slight difference between the cultivars occurred, however, in that in 'Cavendish' ethanol was undetectable but in 'Annapolis' increased by 0.006 $\mu \mathrm{mol} \cdot \mathrm{g}^{-1} \cdot \mathrm{d}^{-1}$ (Fig. 1). In contrast, 'Honeoye' and 'Kent' accumulated large amounts of acetaldehyde and ethanol, the levels being higher in 'Kent' than in 'Honeoye' (Fig. 1). 'Kent' also accumulated much greater levels of ethyl acetate than 'Honeoye'.

Activities of PDC and ADH were affected by cultivar $(P \leq$ $0.001)$, with much lower activities in 'Honeoye' than in the other cultivars (Table 2). Overall, PDC activity was not affected by atmosphere $\left(0.69 \mu \mathrm{mol} \cdot \mathrm{min}^{-1} \cdot \mathrm{g}^{-1}\right.$ fresh weight for both treatments $)$ whereas $\mathrm{ADH}$ activity was $0.80 \mu \mathrm{mol} \cdot \mathrm{min}^{-1} \cdot \mathrm{g}^{-1}$ on a fresh weight basis in $\mathrm{CO}_{2}$-treated fruit compared with $0.73 \mu \mathrm{mol} \cdot \mathrm{min}^{-1} \cdot \mathrm{g}^{-1}$ fresh

Fig. 1. Acetaldehyde, ethanol, and ethyl acetate concentrations $\left(\mu \mathrm{mol} \cdot \mathrm{g}^{-1}\right.$ fresh weight) in fruit of four strawberry cultivars stored in air (open symbols) or 20 $\mathrm{kPa} \mathrm{CO}_{2}$ in air (closed symbols) at $2{ }^{\circ} \mathrm{C}$ for up to $9 \mathrm{~d}$. Vertical bars represent pooled LSD values at $P=0.05$ for the cultivar $\times$ atmosphere $\times$ time interaction.
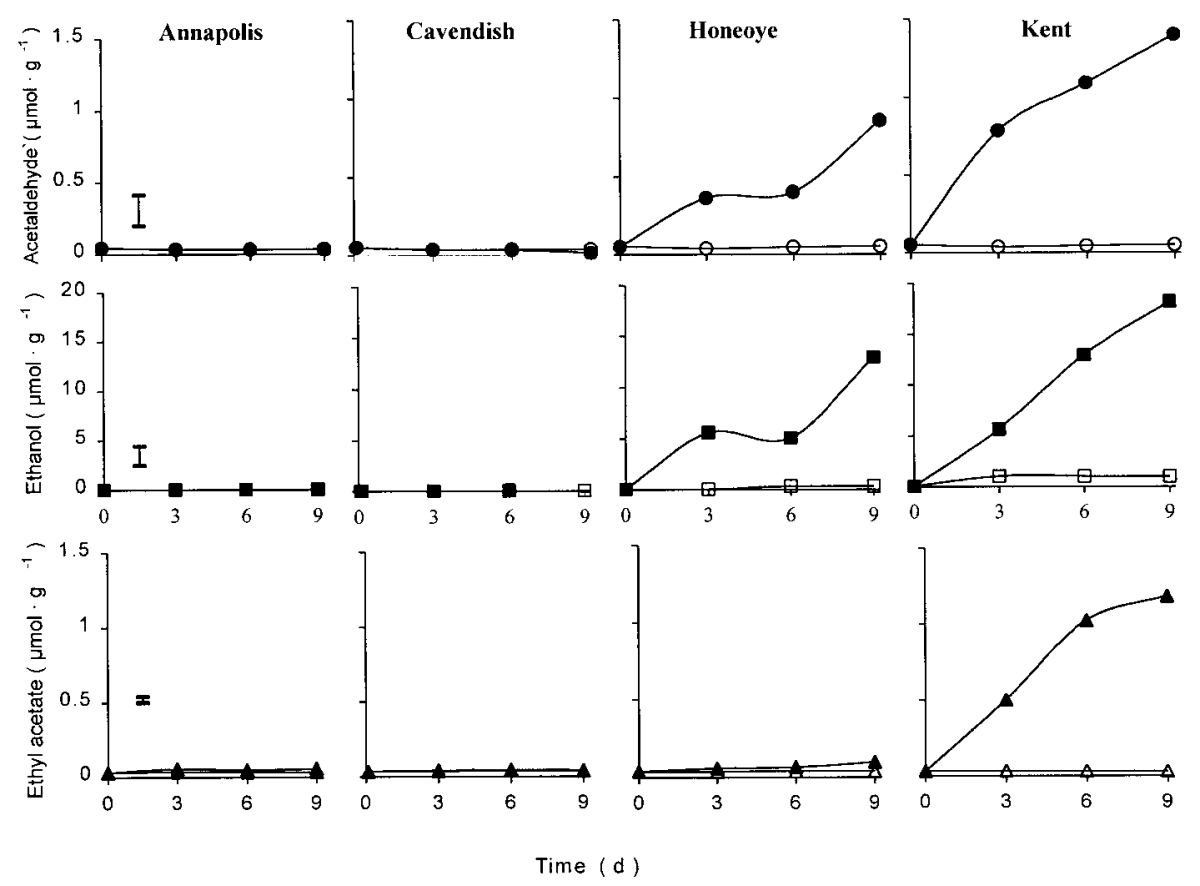
Table 2. Pyruvate decarboxylase (PDC) and alcohol dehydrogenase (ADH) activity in 'Annapolis', 'Cavendish', 'Kent', and 'Honeoye' strawberries stored in air, or $20 \mathrm{kPa} \mathrm{CO}_{2}$ in air, for up to $9 \mathrm{~d}$ at $2{ }^{\circ} \mathrm{C}$. Data for 3,6 and $9 \mathrm{~d}$ have been combined.

\begin{tabular}{|c|c|c|c|c|c|c|c|}
\hline \multirow[b]{2}{*}{ Cultivar } & \multicolumn{3}{|c|}{$\begin{array}{c}\text { PDC } \\
\left(\mu \mathrm{mol} \cdot \mathrm{min}^{-1} \cdot \mathrm{g}^{-1} \text { fresh } \mathrm{wt}\right)\end{array}$} & \multicolumn{4}{|c|}{$\begin{array}{c}\mathrm{ADH} \\
\left(\mu \mathrm{mol} \cdot \mathrm{min}^{-1} \cdot \mathrm{g}^{-1} \text { fresh } \mathrm{wt}\right)\end{array}$} \\
\hline & Air & $\mathrm{CO}_{2}$ & $\mathrm{CO}_{2} / \mathrm{Air}$ & Air & $\mathrm{CO}_{2}$ & & $\mathrm{CO}_{2} / \mathrm{Air}$ \\
\hline Annapolis & 0.71 & 0.76 & 1.07 & 0.85 & 1.04 & & 1.22 \\
\hline Cavendish & 1.01 & 1.18 & 1.17 & 0.80 & 0.96 & & 1.20 \\
\hline Honeoye & 0.34 & 0.27 & 0.78 & 0.42 & 0.39 & & 0.96 \\
\hline \multirow[t]{2}{*}{ Kent } & 0.72 & 0.56 & 0.79 & 0.83 & 0.80 & & 0.93 \\
\hline & df & \multicolumn{6}{|c|}{ Significance (MS and $P$ ) } \\
\hline Cultivar (C) & 3 & \multicolumn{2}{|r|}{$1.654^{* * * *}$} & & \multicolumn{3}{|c|}{$0.850^{* * * *}$} \\
\hline Atmosphere (A) & 1 & \multicolumn{2}{|r|}{$0.000^{\mathrm{NS}}$} & & \multicolumn{3}{|c|}{$0.091^{*}$} \\
\hline Time $(\mathrm{T})$ & 2 & \multicolumn{2}{|r|}{$0.008^{\mathrm{NS}}$} & & \multicolumn{3}{|c|}{$0.064^{*}$} \\
\hline $\mathrm{C} \times \mathrm{A}$ & 3 & \multicolumn{2}{|r|}{$0.097^{* * *}$} & & \multicolumn{3}{|c|}{$0.063^{*}$} \\
\hline $\mathrm{C} \times \mathrm{T}$ & 6 & \multicolumn{2}{|r|}{$0.005^{\mathrm{NS}}$} & & \multicolumn{3}{|c|}{$0.088^{* * * *}$} \\
\hline $\mathrm{A} \times \mathrm{T}$ & 2 & \multicolumn{2}{|r|}{$0.025^{\mathrm{NS}}$} & & \multicolumn{3}{|c|}{$0.012^{\mathrm{NS}}$} \\
\hline $\mathrm{C} \times \mathrm{A} \times \mathrm{T}$ & 6 & \multicolumn{2}{|r|}{$0.043^{* * *}$} & & \multicolumn{3}{|c|}{$0.011^{\mathrm{Ns}}$} \\
\hline Error & 44 & \multicolumn{2}{|r|}{0.009} & & \multicolumn{3}{|c|}{0.017} \\
\hline
\end{tabular}

$\overline{\mathrm{Ns}, *, * * *}$ Nonsignificant or significant at $P \leq 0.05$ or 0.001 , respectively.

weight basis in air-treated fruit $(P \leq 0.01)$. An effect of storage duration was detectable only for $\mathrm{ADH}(P \leq 0.01)$ being $0.76,0.82$, and $0.71 \mu \mathrm{mol} \cdot \mathrm{min}^{-1} \cdot \mathrm{g}^{-1}$ fresh weight on day 3,6 , and 9 respectively. An interaction between cultivar and atmosphere was detected for both enzymes, but particularly PDC. Activities of $\mathrm{PDC}$ and $\mathrm{ADH}$ were higher in $\mathrm{CO}_{2}$-treated than air-treated 'Annapolis' and 'Cavendish', but lower or unaffected by $\mathrm{CO}_{2}$ treatment in 'Honeoye' and 'Kent' (Table 2). ADH activities were affected by cultivar and time, remaining the same or increasing slightly over time in 'Annapolis' and 'Cavendish', but decreasing in 'Honeoye' and 'Kent'. A three-way interaction between cultivar, atmosphere, and time for PDC activity was due to variation in 'Kent' samples; whereas changes in activities were consistent in the other cultivars, PDC activity in $\mathrm{CO}_{2}$-treated 'Kent fruit were slightly lower than in air on day 3, but highest on days 6 and 9.

The two groups accumulated significantly different amounts of succinate, the most accumulation occurring in 'Annapolis', slightly less in 'Cavendish', but overall these two cultivars accumulated $0.8 \mathrm{mmol} \cdot \mathrm{g}^{-1} \cdot \mathrm{d}^{-1}$, which represents $213 \%$ more succinate than 'Honeoye' and 'Kent' (Fig. 2). Ratios of succinate in berries stored in $\mathrm{CO}_{2}$ and air averaged 11.3 in 'Annapolis' and 'Cavendish' and 3.8 in 'Honeoye' and 'Kent'. Malate concentrations were $22 \%$ lower overall in $\mathrm{CO}_{2}$ - than air-treated fruit of all cultivars (Fig. 2). The extent of reduction of malate by $\mathrm{CO}_{2}$ treatment was not affected by cultivar, although overall the effect of cultivar was significant with the highest concentration in 'Annapolis' and the lowest in 'Honeoye'. Data were also examined statistically using presence and absence of fermentation product accumulation as a factor. The overall (air and $\mathrm{CO}_{2}$ treatments) malate concentrations were 12.4 and $15.1 \mu \mathrm{mol} \cdot \mathrm{g}^{-1}$ in those cultivars that did or did not accumu- late fermentation products, respectively.

Other acids, such as citrate/isocitrate, aconitic, oxalate, and quinate were affected by cultivar, but were not affected $\mathrm{CO}_{2}$ treatment (data not shown). However, aconitate concentrations were higher, while quinate concentrations were lower $(P<0.05)$ in cultivars that accumulated fermentation products than those that did not.

EXPERIMENT 3. 'Jewel' fruit were kept in air or high $\mathrm{CO}_{2}$ at 2 or $20^{\circ} \mathrm{C}$ for up to $9 \mathrm{~d}$. However, due to high decay incidence in fruit at $20^{\circ} \mathrm{C}$ after $6 \mathrm{~d}$ storage, $9 \mathrm{~d}$ replicates of fruit were not taken. Acetaldehyde, ethanol, and ethyl acetate accumulated in

Fig. 2. Succinate and malate concentrations $\left(\mu \mathrm{mol} \cdot \mathrm{g}^{-1}\right.$ fresh weight $)$ in fruit of four strawberry cultivars stored in air (open symbols) or $20 \mathrm{kPa} \mathrm{CO}_{2}$ in air (closed symbols) at $2{ }^{\circ} \mathrm{C}$ for up to $9 \mathrm{~d}$. Vertical bars represent pooled LSD values at $P=$ 0.05 for main effects or interactions.
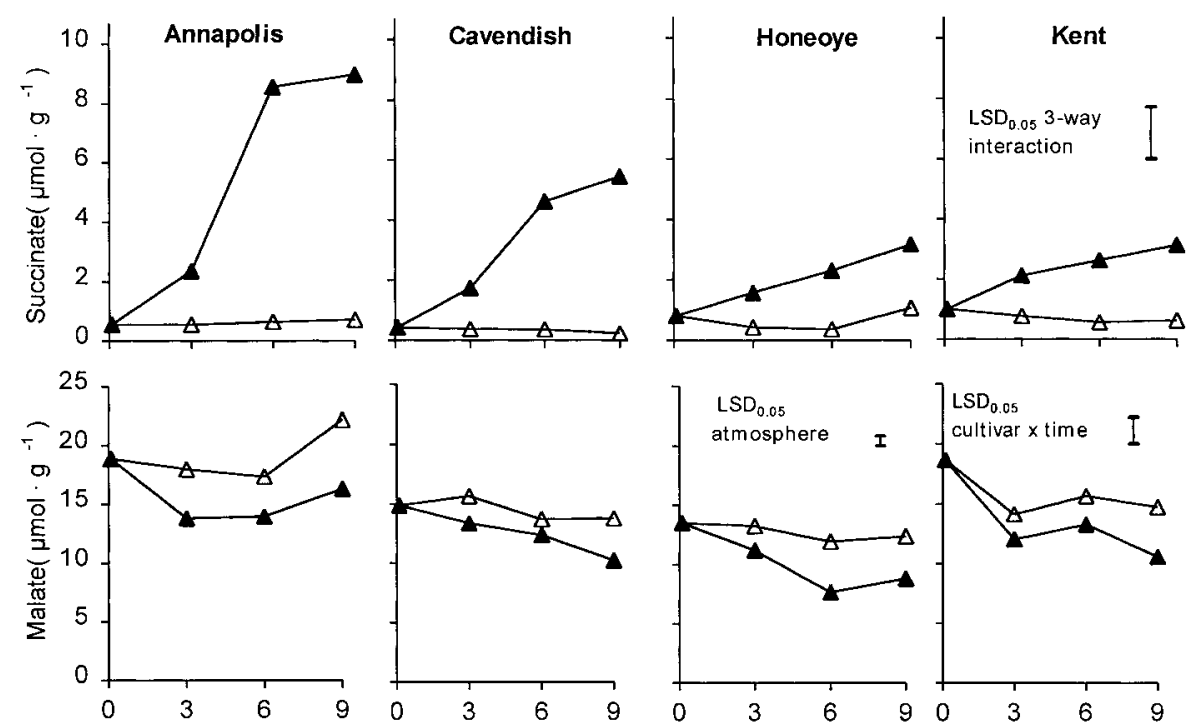


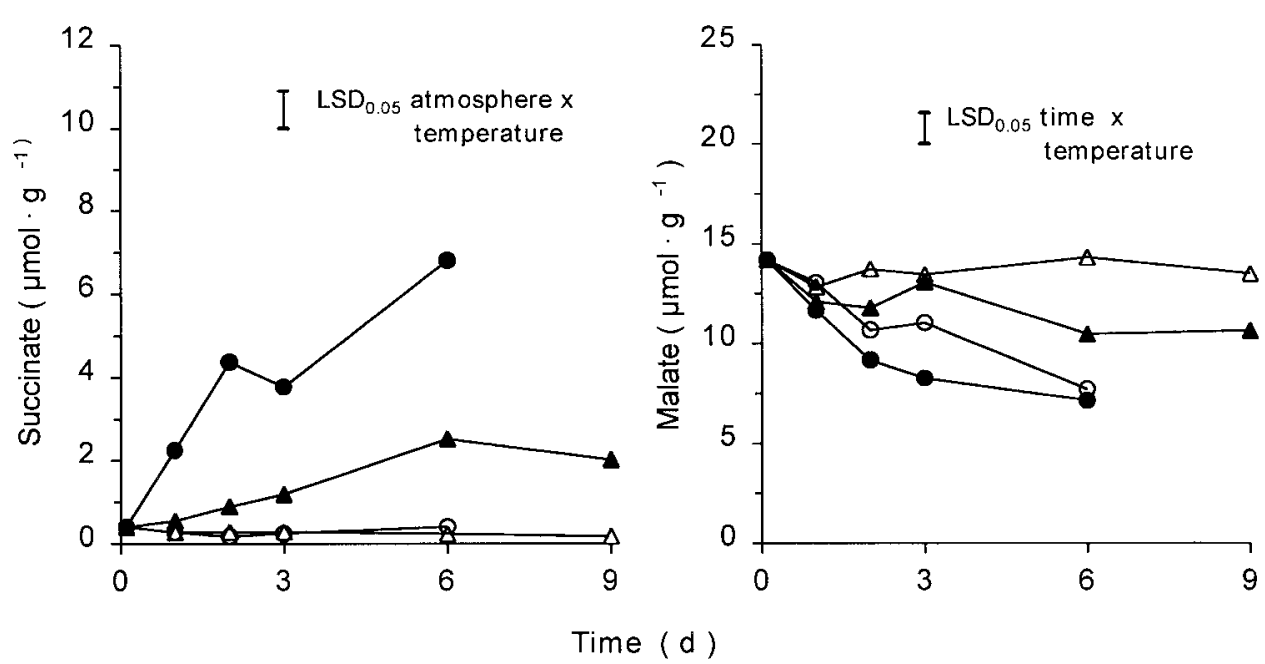

Fig. 3. Succinate and malate concentrations ( $\mu \mathrm{mol} \cdot \mathrm{g}^{-1}$ fresh weight) in 'Jewel' strawberries kept in air (open symbols) or $20 \mathrm{kPa} \mathrm{CO}_{2}$ in air (closed symbols) at $20^{\circ} \mathrm{C}$ for up to $6 \mathrm{~d}$ (circles), or $2{ }^{\circ} \mathrm{C}$ for up to $9 \mathrm{~d}$ (triangles). The vertical bars represent pooled LSD values at $P=0.05$ for main effects or interactions.

fruit treated with $20 \mathrm{kPa} \mathrm{CO}_{2}$ at $2{ }^{\circ} \mathrm{C}$, to maximum levels of 0.5 , 4.4 , and $0.1 \mathrm{mmol} \cdot \mathrm{g}^{-1}$ on day 9 , but not at $20^{\circ} \mathrm{C}$ (data not shown). Succinate also accumulated in $\mathrm{CO}_{2}$-treated fruit but reached much higher levels at $20{ }^{\circ} \mathrm{C}$ than at $2{ }^{\circ} \mathrm{C}$ (Fig. 3). Malate concentrations decreased in fruit held at $20^{\circ} \mathrm{C}$, and also in $\mathrm{CO}_{2^{-}}$ treated fruit compared with air-treated fruit at both temperatures (Fig. 3).

\section{Discussion}

Watkins et al. (1999) found that fermentation products accumulated under $20 \mathrm{kPa} \mathrm{CO}_{2}$ in a cultivar-dependent manner: 'Annapolis' and 'Cavendish' did not accumulate acetaldehyde and ethanol, while 'Honeoye', 'Jewel', 'Kent', and especially 'Governor Simcoe', accumulated large amounts. 'Earliglow' was somewhat intermediate in response. These differences in accumulation of fermentation products may indicate differences in fruit tolerance to high $\mathrm{CO}_{2}$ and therefore provide useful experimental material to investigate metabolism under these conditions.

Results presented herein confirm differences in cultivar response (Figs. 1 and 3; Table 1), and also suggest that 'Lateglow' but not 'Northeast' may accumulate fermentation products under high $\mathrm{CO}_{2}$ conditions. Within cultivars that accumulated acetaldehyde and ethanol, differences in further metabolism to esters such as ethyl acetate are also apparent (Fig. 1), suggesting that fermentative and associated pathways can vary widely among cultivars. This is not surprising considering the quantitative differences of flavor volatiles among ripening cultivars shown by Shamaila et al. (1992). Relationships between off-flavor and fermentation products are affected by different volatile compounds and by cultivar (Ke et al., 1991; Larsen and Watkins, 1995a). Therefore, our data cannot be used to specify fermentation product concentrations responsible for off-flavor development. However, informal assessment of fruit indicated that alcoholic off-flavors were dominant in $\mathrm{CO}_{2}$-treated 'Honeoye' and 'Kent' fruit from day 3 onwards.

Accumulation of acetaldehyde and ethanol occur typically when plant tissues are exposed to anaerobic conditions, and are usually associated with increased activities of $\mathrm{ADH}$ and, less consistently with PDC (Chervin etal., 1999; Drew, 1997; Kennedy et al., 1992; Zhang and Greenway, 1994). Acetaldehyde and ethanol concentrations, together with PDC and ADH activities, also increase when strawberries are treated with $20 \mathrm{kPa} \mathrm{CO}_{2}$, although the relative increases are low compared with those under hypoxia (Ke et al. 1994a, 1994b). The significance of different responses of strawberry cultivars to elevated $\mathrm{CO}_{2}$ with regard to $\mathrm{PDC}$ and $\mathrm{ADH}$ activity is not clear. The less tolerant 'Honeoye' and 'Kent' might be expected to have higher activities of these enzymes in $\mathrm{CO}_{2}$ - than air-treated fruit, since these cultivars accumulate fermentation products. ADH activity, for example, is correlated with ethanol accumulation in other systems (Chan and Burton, 1992). Notwithstanding factors such as differential isozyme activities (Ke et al., 1994b) and possible effects of lowered $\mathrm{pH}$ resulting from carbonic acid formation in $\mathrm{CO}_{2}$ treated fruit on enzyme activity (Bown, 1985), measurement of carbon flux in relation to enzyme activities (Zhang and Greenway, 1994) will be required to understand regulation of fermentation in these cultivars. Interestingly, in vitro PDC and ADH activities (Table 2) are in excess of those required to produce the amounts of acetaldehyde and ethanol measured (Fig. 1), indicating as in other studies (Chervin et al., 1999), that the activities of either enzyme are unlikely to be rate limiting.

Succinate concentrations also showed patterns of change that were affected by tolerance to high $\mathrm{CO}_{2}$ conditions, with highest levels in tolerant fruit (Fig. 2). Also, accumulation of succinate was greater at 20 than at $2{ }^{\circ} \mathrm{C}$ (Fig. 3) and no volatile accumulation was detected in fruit at the higher temperature (data not shown). Accumulation of succinate is a common response to high $\mathrm{CO}_{2}$ in leaves and stems (Ke et al., 1993; Romo-Parada et al., 1989) and fruit (Hulme, 1956; Wagner, 1974; Yang et al., 1998). Its accumulation is thought to be toxic to cells (Hulme, 1956), although Ke et al. (1993) did not find a relationship between succinate accumulation and cultivar susceptibility to $\mathrm{CO}_{2}$ injury of lettuce (Lactuca sativa L.). Little is known about the mechanisms involved in succinate accumulation, but it is usually assumed to be associated with $\mathrm{CO}_{2}$-induced inhibition of succinate dehydrogenase (SDH), which oxidizes succinate to fumarate in the TCA cycle(Frenkel and Patterson, 1973; Ke et al., 1993; Shipway and Bramlage, 1973). Higher succinate accumulation in 'Annapolis' and 'Cavendish' may reflect lower carbon flux through the fermentation pathway and more via the TCA cycle, compared with 'Honeoye' and 'Kent'. Succinate production also may result from activation of the glyoxylate cycle (Yang et al., 1998), the 4aminobutyrate shunt (Satya Narayan and Nair, 1986), and/or phosphoenolpyruvate carboxylase activity (Bisbis et al., 1997). Anaerobic production of succinate is common in animals with high resistance to anoxia (Hochachka and Somero, 1984), and although it has seldom been reported in plants (Bourne and Ranson, 1965), its accumulation may be related similarly to anoxia resistance in some plant species (Menegus et al., 1988, 1989).

Malate concentrations decreased in all $\mathrm{CO}_{2}$-treated strawber- 
ries, perhaps due to decreased recycling of succinate to malate. Its relative decrease was not related to the degree of succinate accumulation (Figs. 2 and 3), however, probably because malate pools are large and also associated with other metabolic pathways. In addition, pyruvate carboxylase activity would result in oxaloacetate production, and consequently maintenance of TCA cycle intermediates such as malate. Interestingly, however, overall concentrations of malate were higher in the two cultivars that accumulated the most succinate.

The marketplace usually rejects produce with accumulations of fermentation products and associated off-flavor development. Cultivars such as 'Annapolis' and 'Cavendish', and 'Honeoye' and 'Kent', would be regarded commercially, as tolerant and intolerant to high $\mathrm{CO}_{2}$ conditions, respectively, under the $\mathrm{CO}_{2}$ atmosphere conditions reported. Differences among cultivars, therefore, have implications for selection of appropriate cultivars for MA and CA storage. Metabolically, however, distinctions between tolerances of cultivars to $\mathrm{CO}_{2}$ based on accumulation of fermentation products raise some interesting questions. Although metabolic distinctions between anaerobiosis associated with high $\mathrm{CO}_{2}$ and low $\mathrm{O}_{2}$ exist, a characteristic of hypoxia-tolerant plants, e.g., under flooding conditions, is an association with sustained, predominantly ethanolic fermentation (Drew, 1997). Fermentation provides a mechanism for pyruvate oxidation and NADH use and ATP production to proceed by substrate phosphorylation, while electron transport and oxidative phosphorylation are inhibited (Kennedy et al., 1992). Production of ethanol by roots, however, provides a mechanism by which leakage of this compound to the external soil medium can occur (Drew, 1997). From this perspective, fermentation in fruit under high $\mathrm{CO}_{2}$ could be interpreted as a mechanism associated with tolerance, rather than intolerance, of fruit. Under ambient conditions, rapid diffusion of volatiles might occur from fruit in a way analogous to release of ethanol from roots; in 'Jewel' strawberries, for example, little accumulation of acetaldehyde or ethanol was detected in fruit kept in $20 \mathrm{kPa} \mathrm{CO}$ at $20{ }^{\circ} \mathrm{C}$ (data not shown). Nevertheless, in contrast to fruit responses to imposed conditions resulting from postharvest treatments, those occurring under natural hypoxiainducing conditions such as flooding, can be seen as adaptive and having evolved to ensure plant survival.

\section{Literature Cited}

Bisbis, B., C. Kevers, and T. Gaspar. 1997. Atypical TCA cycle and replenishment in a non-photosynthetic fully habituated sugarbeet callus overproducing polyamines. Plant Physiol. Biochem. 35:363-368.

Bourne, D.T. and S.L. Ranson. 1965. Respiratory metabolism in detached rhododendrum leaves. Plant Physiol. 40:1178-1190.

Bown, A.W. 1985. $\mathrm{CO}_{2}$ and intracellular pH. Plant Cell Environ. 8:459-465.

Browne, K.M., J.D. Geeson, and C. Dennis. 1984. The effects of harvest date and $\mathrm{CO}_{2}$-enriched storage atmospheres on the storage and shelf-life of strawberries. J. Hort. Sci. 59:197-204.

Chan, J.W.Y. and R.S. Burton. 1992. Variation in alcohol dehydrogeanse activity and flood tolerance in white clover, Trifolium repens. Evolution 46:721-734. Chervin, C., J.K. Truett, and J. Speirs. 1999. Alcohol dehydrogenase expression and alcohol production during pear ripening. J. Amer. Soc. Hort. Sci. 124:7175 .

Couey, H.M. and J.M. Wells. 1970. Low oxygen or high carbon dioxide atmospheres to control postharvest decay of strawberries. Phytopathology 60:47-49.

Drew, M.C. 1997. Oxygen deficiency and root metabolism: Injury and acclimation under hypoxia and anoxia. Annu. Rev. Plant Physiol. 48:223-250.

Frenkel, C. and M.E. Patterson. 1973. Effect of carbon dioxide on activity of succinic dehydrogenase in 'Bartlett' pears during cold storage. HortScience 8:395-396.

Harris C.M. and J.M. Harvey. 1973. Quality and decay of California strawberries stored in $\mathrm{CO}_{2}$-enriched atmospheres. Plant Dis. Rpt. 57:44-46.

Hochachka, P.W. and G.N. Somero. 1984. Limiting oxygen availability, p. 145181. In: P.W. Hochachka and G.N. Somero (eds.). Biochemical adaptation. Princeton Univ. Press, Princeton, N.J.

Hulme, A.C. 1956. Carbon dioxide injury and the presence of succinic acid in apples. Nature 178:218-219.

Ke, D., L. Goldstein, M. O'Mahoney, and A.A. Kader. 1991. Effects of short-term exposure to low $\mathrm{O}_{2}$ and high $\mathrm{CO}_{2}$ atmospheres on quality attributes of strawberries. J. Food. Sci. 56:50-54.

Ke, D., M. Mateos, J. Siriphanich, C. Li, and A.A. Kader. 1993. Carbon dioxide action on metabolism of organic and amino acids in crisphead lettuce. Postharvest Biol. Technol. 3:235-247.

Ke, D., E. Yahia, B. Hess, L. Zhou, and A.A. Kader. 1995. Regulation of fermentative metabolism in avocado fruit under oxygen and carbon dioxide stresses. J. Amer. Soc. Hort. Sci. 120:481-490.

Ke, D., E. Yahia, M. Mateos, and A.A. Kader. 1994a. Ethanolic fermentation of 'Bartlett' pears as influenced by ripening stage and atmospheric composition. J. Amer. Soc. Hort. Sci. 119:976-982.

Ke, D., L. Zhou, and A.A. Kader. 1994b. Mode of oxygen and carbon dioxide action on strawberry ester biosynthesis. J. Amer. Soc. Hort. Sci. 119:971-975. Kennedy, R.A., M.E. Rumpho, and T.C. Fox. 1992. Anaerobic metabolism in plants. Plant Physiol. 100:1-6.

Larsen M. and C.B. Watkins. 1995a. Firmness and concentrations of acetaldehyde, ethyl acetate and ethanol in strawberries stored in controlled and modified atmospheres. Postharvest Biol. Technol. 5:39-50.

Larsen M. and C.B. Watkins. 1995b. Firmness and aroma composition of strawberries following short-term high carbon dioxide treatments. HortScience 30:303-305.

Mattick, L.R., A.C. Rice, and J.C. Moyer. 1970. Determination of the fixed acids in musts and wines by gas chromatography. Amer. J. Enol. Viticult. 21:179183.

Menegus, F., L. Cattaruzza, A. Chersi, and G. Fronza. 1989. Differences in the anaerobic lactate-succinate production and the changes of cell sap $\mathrm{pH}$ for plants with high and low resistance to anoxia. Plant Physiol. 90:29-32.

Menegus, F., L. Cattaruzza, A. Chersi, A. Selva, and G. Fronza. 1988. Production and organ distribution in rice seedlings during anoxia. Physiol. Plant. 74:444449.

Mitchell, F.G. 1992. Postharvest handling systems: Small fruits (table grapes, strawberries, kiwifruit), p. 223-231. In: A.A. Kader (ed.). Postharvest technology of horticultural crops. 2nd ed. Univ. Calif., Oakland, Publ. 3311.

Mitchell, W.C. and G. Jelenkovic. 1995. Characterizing NAD- and NADPdependent alcohol dehydrogenase enzymes of strawberries. J. Amer. Soc. Hort. Sci. 120:798-801.

Nanos, G.C., R.J. Romani, and A.A. Kader. 1992. Metabolic and other responses of 'Bartlett' pear fruit and suspension-cultural 'Passe Crassane' pear fruit cells held in $0.25 \%$ O . J. Amer. Soc. Hort. Sci. 117:934-940.

Reyes, F.G.R., R.E. Wrolstad, and C.J. Cornwall. 1982. Comparison of enzymic, gas-liquid chromatographic, and high performance liquid chromatographic methods for determining sugars and organic acids in strawberries at three stages of maturity. J. Assn. Offic. Anal. Chem. 65:126-131.

Romo-Parada, L., C. Willemot, F. Castaigne, C. Gosselin, and J. Arul. 1989. Effect of controlled atmospheres (low oxygen, high carbon dioxide) on storage of cauliflower (Brassica oleracea L., Botrytis group). J. Food Sci. 54:122-124, 158.

Satya Narayan, V. and P.M. Nair. 1986. The 4-aminobutyrate shunt in Solanum tuberosum. Phytochemistry 25:997-1001.

Shamaila, M., T.E. Bauman, G.W. Eaton, W.D. Powrie, and B.J. Skura. 1992. Quality attributes of strawberry cultivars grown in British Columbia. J. Food Sci. 57:696-699, 720.

Shipway, M.R. and W.J. Bramlage. 1973. Effects of carbon dioxide on activity of apple mitochondria. Plant Physiol. 51:1095-1098.

Wagner, H.G. 1974. The effect of subjecting peas to air enriched with carbon dioxide. II. Respiration and the metabolism of the major acids. J. Expt. Bot. 25:338-351.

Watkins, C.B., J.E. Manzano-Mendez, J.F. Nock, J.J. Zhang, and K.E. Maloney. 1999. Cultivar variation in response of strawberry fruit to high carbon dioxide treatments. J. Sci. Food Agr. 79:886-890.

Yang, Y., H. Murayama, and T. Fukushima. 1998. Activation of glyoxylate cycle enzymes in cucumber fruits exposed to $\mathrm{CO}_{2}$. Plant Cell Physiol. 39:533-539.

Zhang, Q. and H. Greenway. 1994. Anoxia tolerance and anaerobic catabolism of aged beetroot storage tissues. J. Expt. Bot. 45:567-575. 